\title{
Assessing The Awareness, Attitude And Perception Of Adolescents For HIV/AIDS Education In Nigeria: The Case Study Of Sagamu Remo Ogun State.
}

\author{
Omeonu P E, Agbede C O and Emea M K \\ ${ }^{I}$ Department of Public Health, Babcock University, Ilishan-Remo, Ogun State, Nigeria.
}

\begin{abstract}
Information on the management of HIV/AIDS especially among adolescents is of growing concern globally. This study assessed the awareness, attitude and perception of adolescents for HIV/AIDS among secondary school students in Sagamu-Remo, Ogun state, Nigeria. Using multi-stage sampling, 400 students were selected from Remo Secondary School (coded as S1) and Remo Divisional High School (coded as S2). Structured questionnaire was used to collect data to measure awareness, attitude and perception about HIV and AIDS. The data were presented as descriptive statistics subjected to independent $t$-test statistics at $p \leq 0.05$ level of significance. Mean age, for S1 and S2 respectively, was $15.54 \pm 1.46$ and $15.22 \pm 1.78$. The differences in all measured variables for both schools were not significant. The mean scores for awareness level for S1 and S2

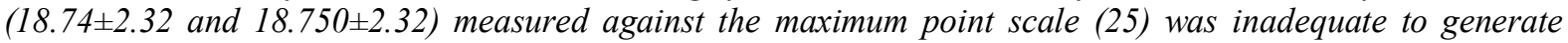
sufficient conscious preventive behaviour among this age group especially if confronted with the choice of a risky sexual behaviour. Further results showed fairly high and positive attitude for the participants $(79 \%$ for SI and S2) but very low perception (49.6\% and 49.5\% for S1 and S2 respectively). The need to raise awareness of the target population through education is recommended.
\end{abstract}

Keywords: Adolescents, awareness, attitude, HIV/AIDS, Nigeria, perception.

\section{Introduction}

Acquired Immune Deficiency Syndrome (AIDS) was first detected as distinct entity in the United States in 1981, the first several hundreds of people diagnosed were homosexual men [1]. Since then, HIV and AIDS has become a worldwide epidemic spreading rapidly but unevenly, across continents, countries, age groups and socio-economic classes. HIV and AIDS burden continues to bear negative impact on GDP growth rate in Africa translating to between $0.3 \%$ and $0.6 \%$ decrease in GDP growth [2]. Nigeria carries the second heaviest burden of HIV in Africa and has an expanding population of People Living with HIV (PLHIV) [3]. UNAID [4] figures puts the global population of adolescents living with HIV at 5.4 million, which accounts for one third of the total global population living with HIV and AIDS on the average. Millions of young people living with HIV do not know they are infected, and every day, approximately 2,100 adolescents and young people are newly infected, which accounts for 39\% of all new HIV infections globally. Many of these victims live in developing countries particularly Sub-Saharan Africa, of which Nigeria is included. The disease continues to ravage Sub-Saharan Africa and it remains one of the most serious infectious disease that is challenging Africa and one of the leading causes of death in Sub-Saharan Africa [5].

The reality of the devastating effects of HIV and AIDS on the global economy, especially developing countries like Nigeria, is not in doubt, nor is the social stigma that goes with the sufferers of the disease anymore news [5]. In Nigeria, despite substantial awareness of how to effectively prevent HIV, including condom promotion abstinence promotion e.g. Zip up, peer education [6], teachers education [7], there is evidence that many adolescents lack adequate education about HIV and AIDS [8]. The main objective of this study is to assess the awareness and attitude of adolescents to HIV/AIDS education among secondary school students in Sagamu- Remo, Ogun state, Nigeria.

\subsection{Awareness, Perception and Attitude of Adolescents to HIV and AIDS}

Attitude is determined through an assessment of one's beliefs regarding the consequences arising from behaviour and an evaluation of the desirability of these consequences [9]. Young people are particularly at risk of HIV infection due to their poor perception and attitude toward preventive measures, such as determining their HIV status, abstinence from sexual relationship or use of condom during coitus [10]. Measuring the perception of adolescents with respect to HIV and AIDS ascertains the level of their conscious awareness and interpretations regarding the likelihood of becoming infected if they have unprotected sexual intercourse or the nature of the outcome of an infection with HIV. The study of Odu and Akanle [11] posited that there is a nexus between awareness perception and attitude; hence behaviour or practice is shaped by these variables. This 
implied that having enough education of prevention, transmission and other facts about HIV and AIDS could motivate logical safe sex behaviour.

\subsection{HIV and AIDS in Ogun State}

Ogun State was ranked the third place in terms of the population of people living with Human Immuno Virus (HIV) in the South-West zone of Nigeria as at 2011 [12]. The Ogun State Government disclosed that the number of people living with HIV and AIDS in the State has risen from 300,000 to 400,000. Further report stated that the prevalence rate, which kept rising and falling and maintaining an undefined pattern since 1996, implied that the State was not winning the war against HIV and AIDS [13]. Awareness education in all secondary and tertiary institution has been identified as a measure to combat HIV and AIDS in the state. Other measures include HIV testing and counseling, and provision of anti-retroviral drugs.

\section{Methodology}

The study was carried out in Sagamu- Remo, Ogun state, Nigeria. The multi-stage sampling was employed to select 400 participants from two model public secondary schools (Remo division high school subsequently called S1 and Remo secondary school subsequently called S2). The first stage was the purposive selection of the two schools followed the random selection of 200 students from each of the schools.

Structured questionnaire was designed to collect data on awareness and attitude of the respondents. The data collected were subjected to descriptive and test statistics (using t-test). Frequency distribution was used to describe respondent's personal characteristics, while the psychometric scale measurement was employed to assess respondent's awareness of HIV and AIDS and attitudinal dispositions about HIV and AIDS. All measured variable responses were dichotomous and coded 0 corresponding to wrong response while 1 corresponded to correct response. All the responses were aggregated to create a scale measuring awareness, attitudinal dispositions and perception. Awareness variables were measured on an aggregated 25-point scale, attitudinal dispositions about HIV and AIDS were measured on an aggregated 8-point scale while all the responses for perception sub-domain were aggregated to create a scale measuring over all Perception on a 54point scale. From these, means scores were computed for all the variables. The t- test was used to examine significant difference in the means of awareness level and attitude of HIV and AIDS between the two schools. All tests were set at $\mathrm{p} \leq 0.05$

\section{Result And Discussion}

\subsection{Demographic Characteristics of the Participants}

From Table 1, the mean age for S1 and S2 were $15.54 \pm 1.46$ and $15.22 \pm 1.78$ respectively. Gender distribution was $50.25 \%$ males and $49.75 \%$ females in S1 while in S2, was $51.75 \%$ male and $48.25 \%$ females. It was also observed that the major proportion of the participants from the S1 (95.03\%) and S2 (95.0\%) are from the Yoruba ethnic group. Christians also formed the greater proportion of the S1 $(70.65 \%)$ and S2 $(70.5 \%)$ schools.

Table 4.1: Distribution of Demographic Characteristics of the Participants.

\begin{tabular}{|c|c|c|c|c|}
\hline \multirow[t]{2}{*}{ VARIABLES } & \multicolumn{2}{|l|}{$\begin{array}{l}\mathbf{S 1} \\
\mathbf{N}=\mathbf{2 0 0}\end{array}$} & \multicolumn{2}{|l|}{$\begin{array}{l}\mathrm{S2} \\
\mathrm{N}=\mathbf{2 0 0}\end{array}$} \\
\hline & Frequency & $\begin{array}{l}\text { Percent } \\
\%\end{array}$ & Frequency & $\begin{array}{l}\text { Percent } \\
\% \\
\end{array}$ \\
\hline Mean Age $(\bar{X} \pm S D)$ & $15.22 \pm 1.78$ & & $15.54 \pm 1.46$ & \\
\hline \multicolumn{5}{|l|}{ Study Groups } \\
\hline - $\quad$ SS 1 & 101 & 50.50 & 126 & 64.50 \\
\hline SS 2 & 99 & 49.50 & 71 & 35.50 \\
\hline \multicolumn{5}{|l|}{ Gender: } \\
\hline Male & 101 & 50.50 & 207 & 51.75 \\
\hline - $\quad$ Female & 99 & 49.50 & 193 & 48.25 \\
\hline \multicolumn{5}{|l|}{ Religion: } \\
\hline - $\quad$ Christian & 142 & 70.65 & 141 & 70.5 \\
\hline Islam & 58 & 29.35 & 59 & 29.5 \\
\hline
\end{tabular}

Source: Field Survey, 2013

\subsection{Awareness level, attitudinal disposition and perception of respondents to HIV and AIDS.}

Results in Table 2 shows awareness variable for S1 group measured on a 25-point scale reported a mean score of $18.74 \pm 2.32$ while S2 group scored a mean of $18.750 \pm 2.32$. Comparing the two mean scores, there was no significant difference between these mean scores $(\mathrm{p}=0.958)$ showing similarity in awareness level in the two schools. This result also indicated $75 \%$ awareness rating. Though high, it appears to be inadequate to generate sufficient conscious preventive behaviour among this age group especially if confronted with the 
choice of a risky sexual behaviour [6].

The participants in the S1 reported a mean score of $6.30 \pm 0.98$ for attitudinal disposition while S2 scored a mean of $6.30 \pm 0.98$ (Table 2). Comparing the two mean scores for attitudinal disposition about HIV and AIDS issues showed that there was no significant difference between the two schools $(\mathrm{P}=0.960)$. Hence it may be contrived that the two schools appear to exhibit similarities in attitudinal dispositions. Attitudinal disposition scores also showed fairly high and positive attitude for the participants (Rated from mean scores at $79 \%$ ). This shows that appropriate behaviour can be aroused among these students given adequate and appropriate education related to HIV and AIDS and communicated through appropriate channels.

Table 2: Respondents' Awareness about HIV and AIDS

\begin{tabular}{|c|c|c|c|c|c|c|}
\hline \multirow[t]{2}{*}{ VARIABLES } & \multirow{2}{*}{$\begin{array}{c}\text { Maximum Points on } \\
\text { Scale of } \\
\text { Measure }\end{array}$} & \multicolumn{2}{|c|}{$\begin{array}{c}\mathrm{S1} \\
\mathbf{N}=\mathbf{2 0 0}\end{array}$} & \multicolumn{2}{|c|}{$\begin{array}{c}\mathrm{S2} \\
\mathrm{N}=\mathbf{2 0 0}\end{array}$} & \multirow{2}{*}{$\begin{array}{c}\text { Level of } \\
\text { Significance } \\
\text { P-value } \\
\end{array}$} \\
\hline & & $\overline{\mathrm{X}}$ & $\pm \mathrm{SD}$ & $\overline{\mathrm{X}}$ & $\pm \mathrm{SD}$ & \\
\hline Awareness level & 25 & 18.741 & 2.324 & 18.750 & 2.322 & 0.958 \\
\hline $\begin{array}{l}\text { Attitudinal } \\
\text { Disposition scale }\end{array}$ & 8 & 6.304 & 0.979 & 6.30 & 0.981 & 0.960 \\
\hline $\begin{array}{l}\text { Overall Perception of } \\
\text { HIV and AIDS }\end{array}$ & 54 & 26.771 & 5.735 & 26.750 & 5.738 & 0.958 \\
\hline \multicolumn{7}{|c|}{$\begin{array}{l}\text { Perception Sub-variable } \\
\end{array}$} \\
\hline $\begin{array}{l}\text { Perceived } \\
\text { Susceptibility }\end{array}$ & 18 & 8.164 & 3.121 & 8.150 & 3.123 & 0.949 \\
\hline Perceived Severity & 8 & 5.774 & 1.422 & 5.775 & 1.424 & 0.989 \\
\hline $\begin{array}{l}\text { Perceived } \\
\text { Barrier/Benefits }\end{array}$ & 16 & 10.077 & 2.491 & 10.075 & 2.477 & 0.990 \\
\hline $\begin{array}{l}\text { Perceived Self- } \\
\text { Efficacy }\end{array}$ & 12 & 3.725 & 1.380 & 3.73 & 1.38 & 0.948 \\
\hline
\end{tabular}

Source: Field Survey, 2013

The results for perception variable are presented and also reported as sub-variables (Sub-scales measures) of perceived susceptibility, perceived severity, perceived self-efficacy expectations of carrying out a defined sexual risk-reduction behaviour, perceived barriers imposed in performing specific sexual risk-reduction behaviour and perceived benefits in behaving in a specified way to reduce likelihood of an infection. All the responses were aggregated to create a scale measuring Perception variable on a 54-point scale. S1 reported mean of $26.77 \pm 5.74$ while S2 scored a mean of $26.75 \pm 5.74$ for perception about HIV/AIDS (Table 2). These mean scores for the participants translate to a $49.6 \%$ and $49.5 \%$ respectively of the perception required to enable them engage in sexual risk-reduction behaviour which is rather too low. Between the two schools, there was no significant difference $(\mathrm{P}=0.958)$ in level of perception conceived. Perceived susceptibility sub-scale regarding HIV/AIDS infectivity measured on 18-point scale reported mean score of $8.16 \pm 3.12$ for $\mathrm{S} 1$ and $8.15 \pm 3.12$. The implications of the below average scores for perceived susceptibility for the two groups reflects poor understanding of the nature of risk exposure involved in HIV/AIDS and consequently how to deal with riskreduction issues. For perceived severity sub-variable measured on 8-point scale, for participants in S1, mean score was $5.77 \pm 0.98$ while mean score for S2 was $5.78 \pm 1.43$. The results for perceived severity reported for the two groups appear better than what was reported for perceived susceptibility; however there is still need to correct certain impressions about HIV/AIDS risk exposure. Perceived barrier towards HIV/AIDS risk-reduction practices is conceived to measure the extent of challenges experienced by respondents to act in protection of infection. This sub-variable was measured on a 16-point scale where high scores indicate high barrier and low scores correspond to high perceived benefits. The participants in S1 reported a mean score of $10.08 \pm 2.50$ while $\mathrm{S} 2$ scored a mean of $10.08 \pm 2.48$. The mean scores for the two groups show that barriers/constraints appear higher than any benefits which respondents may perceive and this may have some influence on their ability to effect risk-reduction sexual behaviour. On the whole, generally, the overall perception appears to be below average which reflects poor interpretations of the meaning of the risk they are exposed to in regards to HIV/AIDS-related sexual risks and how to deal with risk reduction issues. Combining this result with attitudinal disposition above, the need for raising awareness of the target population through education is again reaffirmed.

\section{Conclusion And Recommendations}

This study assessed the awareness, attitude and perception of adolescents to HIV/AIDS education among secondary school students in Sagamu- Remo, Ogun state, Nigeria. Two secondary schools were selected and a total of 400 students were finally selected for the study from the two schools. The demographic factors examined in this study include age, gender and religion affiliation of the respondents. Furthermore, the awareness level, attitudinal disposition and perception of the respondents with respect to HIV and AIDS were measured and compared across the two schools. 
Based on the results, the incorporation of HIV and AIDS education into the school curricular and cocurricular activities in the secondary school education policy is pertinent and can be a successful way of influencing behavioural changes in the adolescent from an early stage of life that will reduce HIV risks. Research into effective intervention measures to corroborate existing awareness campaigns should be encouraged

\section{References}

[1]. Howard M, McCabe J, Helping teenagers' post-pone sexual involvement. Family Planning Perspectives 4 (2), 1990, 75-82.

[2]. Adomakoh Sarah A, Social and Economic costs of HIV and AIDS Current issues Associates for International Development retrieved August 2013 from http://www.europarl.europa.eu/intcoop/acp

[3]. World Fact, people leaving with HIV/AIDS CIA, 2012, accessed February 2013 from www.worldfact.com

[4]. UNAIDS, UNAIDS Report on the AIDS Epidemic Geneva, 2012, accessed February 2013 from. www.unads.org/unaids.

[5]. The World Gazetteer, Theoretical and empirical review. In T. Edgar, S. M. Noar, \& V. Freimuth (Eds.), Communication perspectives on HIV/AIDS for the 21 st century. New York, NY: London Sage Publications, 2013, 3-28.

[6]. Ajuwon, A. J., Olley, B. O., Akin-Jimoh, I., and Akintola, A, Experience of sexual coercion among adolescents in Ibadan, Nigeria African Journal of Reproductive Health, 5(3), 2007, 120- 130.

[7]. Ajuwon, A.J and Brieger, W.R, Evaluation of a school-based reproductive health education program in rural south western, Nigeria. African Journal of Reproductive Heatlth, 11 (2), 2007, 47-59

[8]. Ajuwon A. J, Benefits of sexuality education for young people in Nigeria.Seminar Series 3.African Regional Health Education Centre Department of Health Promotion and Education College of Medicine University of Ibadan, 2002. Retrieved on September 2012 from http://www.arsrc.org/downloads/uhsss/ajuwon.

[9]. Eagly, A. E., and Chaiken, S, Attitude strength, attitude structure and resistance to change. In R. Petty \& J. A. Krosnick (Eds.), Attitude strength: Antecedents and consequences, Mahwah, NJ: Lawrence Erlbaum Associates, 1995, 413-432.

[10]. Omeonu P.E and Kollie, Erhuvwukorotu S, Knowledge and attitude of Babcock University students on risk behaviours of HIV/AIDS acta SATECH 3(2), 2011, $135-142$

[11]. Odu, B. K, and Akanle F. F, Knowledge of HIV/AIDS and Sexual Behaviour among the Youths in South West Nigeria. Humanity \& Social Sciences Journal 3 (1), 2008, 81-88.

[12]. NBS (2007). Nigeria Bureau of Statistics. Annual Abstract of Statistics.

[13]. Dimeji K A, HIV/AIDS statistics in Ogun state. Premium times news, Published in November 29, 2013 